\title{
Mechanical Properties Of Glass Fibers Reinforced Composites: A Concise Review
}

\author{
Mitali Dugvekar ${ }^{1}$, Dr. Savita Dixit ${ }^{2}$ \\ ${ }^{1}$ Research Scholar, Department of Chemistry,MANIT, Bhopal \\ ${ }^{2}$ Professor, Department of Chemistry, MANIT, Bhopal
}

Article History:Received:11 January 2021; Accepted: 27 February 2021; Published online: 5 April 2021

\begin{abstract}
The utility of composites in today's modern world is not hidden from anyone. From tiny objects like football to aerospace, everything involves the use of composites. Composites nearly form the backbone of our society. Composites are basically made from matrices and reinforcement. Out of the majority of reinforcement being used, Glass fibers usage cannot be neglected. These are made of fine fibers of glass (made of $\mathrm{SiO}_{2}$ ). They are used to reinforce various materials like arrows, bows and crossbows, translucent roofing panels, tent poles, boat hulls and paper honeycomb. This review paper is a study of various research papers related to mechanical properties of glass fibers when used with different type of matrices namely, tensile strength, impact strength and flexural strength.
\end{abstract}

Keywords: Composites; Glass fiber; Reinforcement; Mechanical properties; strength.

\section{INTRODUCTION:}

Composites also called Fiber reinforced plastic are simply combination of various components in particular composition. These components have different properties on individual level but end up building a much stronger material. They do not lose their individual identity totally; they combine and contribute their most useful traitsto improve the outcome or final product. The two materials work together to give the composite unique properties.

Composite consist of matrix and reinforcement. Matrix is basically a medium in which the reinforcement is embedded. The matrix is of three types: ceramic, polymeric and metallic. Reinforcement used in building the composite can be either fibrous or non fibrous in nature. Fibers are either derived from sources like plant or any other living species [1] or they can be made artificially. Artificial fibers offer many advantages over natural ones. They show more durability than natural fibers also they show properties like stain resistance, waterproofing and also water resistance. Natural fibers in addition, show high moisture absorption because of the presence of groups like hydroxy or any other polar group which further deteoriates the mechanical properties of the composite. Such effects of environment have been reported on the natural fibers like sisal, wood flour etc. [2-8]

\section{Types of fibers:}

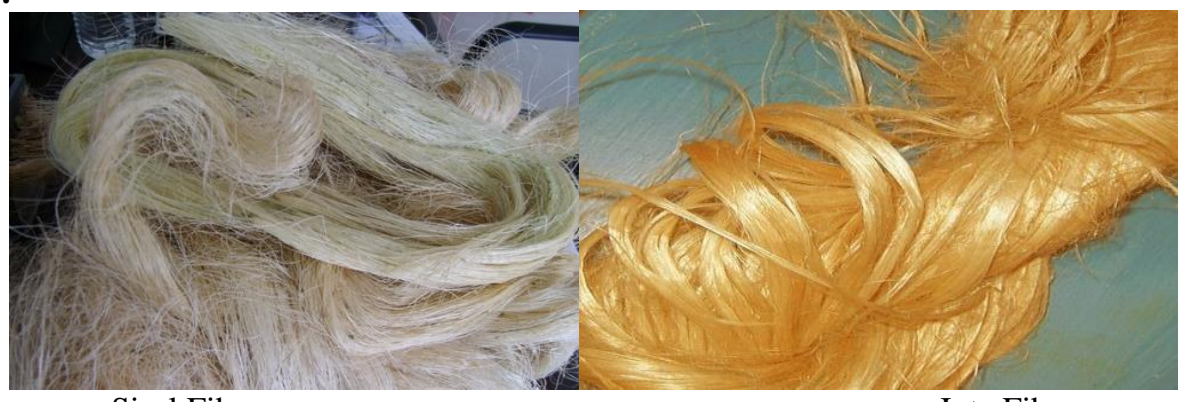

Sisal Fiber

Jute Fiber

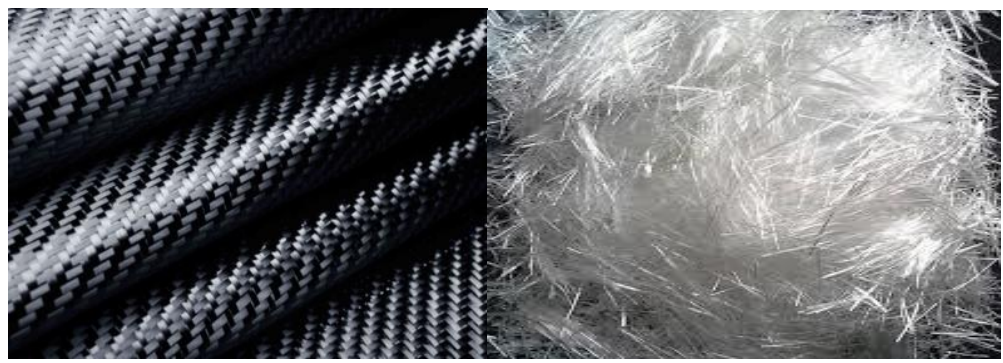

Carbon Fiber

Glass Fiber

Fig:1 Types of Fibers 
Glass fiber is a type of reinforcement used in polymer composites which are made of extremely fine fibers of glass. The glass fibers can be used in many ways. They can either be woven into simple fabric, flattened or even randomly arranged, all of which further alters the mechanical properties of the composite synthesized. One of the reason that glass fibers are in extreme use in present scenario is its ability to get molded into various complex shapes. Also they offer many advantages like strength, light weightness and less brittle. Whereas the plastic resins are strong in compressive loading and relatively weak in tensile strength the glass fibers are very strong in tension but tend not to resist compression. By combining the two materials, GRP becomes a material that resists both compressive and tensile forces well. [9] The two materials may be used uniformly or the glass may be specifically placed in those portions of the structure that will experience tensile loads. [10,11]

The mechanical properties of Fiberglass vary considerably when different types of matrix materials are used with glass fibers. This paper reviews the mechanical properties of composites made from glass fiber when different matrix are used with it.

\section{Glass Fiber: An Introduction}

Depending on the raw materials used and their proportions to make fiberglass, glass fiber can be classified into 5 major types:

A glass: A glass is made with Soda lime silicate. It is resistant to chemicals and is used predominantly in making containers and window panes.

C Glass: C glass is corrosion resistant glass which is made from Portland cement. Thus it is also called chemical glass.

D Glass: This glass is used in electrical applications. It is made with borosilicates.

E Glass: E glass is by far the most commonly used glass and is also least expensive. It is very good conductor of electricity. It is known for its good strength and electrical resistivity.

R Glass: It is reinforcement glass and is used where acid corrosion resistance and higher strength is needed.

S Glass: Also called as structural Glass and is used where high strength, high stiffness, temperature resistance and corrosion resistance is needed. Table 1 shows the mechanical properties of different types of glass fibers

TABLE 1. SHOWS THE MECHANICAL PROPERTIES OF DIFFERENT TYPES OF GLASS FIBER

\begin{tabular}{|l|l|l|l|}
\hline Type of glass fiber & Tensile Strength & Modulus & Density \\
\hline A Glass & 3300 & 72 & 2.44 \\
\hline C Glass & 3300 & 69 & 2.56 \\
\hline D Glass & 2500 & 55 & 2.11 \\
\hline E Glass & 3400 & 72 & 2.54 \\
\hline R Glass & & & 2.52 \\
\hline S Glass & 4400 & 86 & 2.53 \\
\hline
\end{tabular}




\section{Fiberglass:}

The composites which are made by using glass fiber as the reinforcing material are called Glass Fiber Reinforced Polymer (GFRPs) or simply Fiberglass. The earliest patent in production of glass fiber was awarded to the Prussian inventor Hermann Hammesfahr (1845-1914) in U.S. in 1880 [12, 13].

Glass fibers offer many advantages over other fibers although strength properties are somewhat lower than carbon fiber. They are highly cost effective, corrosion resistant, show good structural strength are also have ability to be molded to precise tolerances. Its bulk strength and weight properties are also very favorable when compared to metals, and it can be easily formed using molding processes. [14] Glass fibers work well with epoxy, polyester, and other thermosetting plastics. Common uses of fiberglass include in boats, automobiles, oil and gas, metal processing, mining and minerals etc. [15] Fiberglass composites are an extremely versatile family of materials that are highly customizable and offer several advantages over traditional materials.

\section{Glass fiber reinforced polymer (GFRP):}

Jiang Zhu et al. [16], processed vinyl ester composite reinforced with glass fiber in which carbon nanotube was used for enhancement of interlaminar shear strength. Carbon nanotube was coated onto fiberglass fabric using coating system and then it was processed into vinyl ester laminates. The short beam shear test (SBS) was conducted on a three point bending rig over a span of $40 \mathrm{~mm}$ (1.75 in.) in accordance with standard ASTM D2344-84 [17]. It was observed that the all specimens with nanotubes exhibited increased shear strength by about $45 \%$ compared to the control composite specimen also prepared without any treatment. This new technique called VARTM was introduced due to which the shear strength increases considerably.

Shang-Han Wu et al[18]prepared nanocomposites using polyamide 6 and polyamide 6/clay with glass fibers as reinforcing material. Samples were examined for impact strength (measured by TMI Testing Machine), heat distortion temperature (measured by heat distortion temperature testing machine), flexural strength( measured by Testometric Micro 500) and three point bending test (performed in an Instron test machine; model 4468). It was observed that Tensile and flexural strength and modulus of the both composite systems increased with fiber content, while impacting strength of the composites decreased with fiber content. It was seen that that the tensile strength of polyamide- 6/clay containing $30 \mathrm{wt}$ \% glass fiber was $11 \%$ higher than polyamide-6 containing $30 \mathrm{wt} \%$ glass fiber. As with flexural modulus, it was seen that the flexural strength and flexural modulus of neat polyamide-6/clay was nearly close to polyamide- 6 containing $20 \mathrm{wt} . \%$ glass fiber.

J.L. Thomason et.al [19] studied the effect of fiber length and concentration on polypropylene composites which were made by reinforcing glass fibers. The samples were tested for the tensile, flexural and stiffness tests. It was seen that the tensile, flexural strength increased with increase in fiber concentration. The modulus increased linearly with fiber content upto $40 \%$ above which increase is not linear. Modulus is also affected by glass fiber length, it becomes independent of fiber length above $0.5 \mathrm{~mm}$.

D.M. Laura et.al. [20] studied the effect of glass fiber surface chemistry on the mechanical properties of glass fiber reinforced nylon-6. Glass fiber was treated with different type of interfacial coupling agents. The glass fiber which was treated with anhydride silane as the coupling agent show the highest value of impact strength and yield strength as compared to amine silane which gave lowest. The epoxy silane gave values intermediate of two. This was due to maximum adhesion of fiber with matrix in case of anhydride silane. On the other hand, increase in thermal properties and modulus was seen in case of octyl silanes.

\section{Glass fiber reinforced polymer (GFRPs) compared to other fiber reinforced polymers:}

Christopher Wonderly et.al. [21]studied the mechanical properties of carbon fiber and glass fiber reinforced vinyl ester composites and thus compared them. The glass fiber being used was Owens Corning 111A glass fibers. Samples were studied for Tensile strength and compressive strength. Results of tensile strength test clearly showed that the carbon fiber specimens were more strong as compared to glass fiber specimen. [22] Talking about the compression test results, the damage is more localized in carbon specimens and the standard deviation for glass fiber is less.

S Mishra et.al. [23] studied the effect of glass fiber addition on the mechanical properties (Tensile, Flexural and Compressive) of Pineapple leaf fibers and sisal fibers reinforced polyester composites. Also they studied the effect of glass fiber addition on the water absorption capacities of these composites. It was observed that the tensile and 
flexural strength of the pineapple-polyester as well as sisal-polyester specimens was increased on addition of glass fiber. A net increase of tensile strength by about $66 \%$ was observed on addition of $8.6 \%$ glass fiber to PALFpolyester specimen. Between PALF and Sisal, later showed improved mechanical properties on addition of glass fiber. The impact strength was also found to considerably increase on addition of glass fiber but after $12.9 \%$ onwards, it showed no considerable effect.

Kasama Jarukumjorn [24] studied the mechanical properties of glass fiber reinforced natural fiber composite. They reported the various works of scientist related to glass fiber enhancement of mechanical properties. They reported that that tensile strength and elastic modulus of bamboo fiber reinforced polypropylene (BFRP) and bamboo-glass fiber reinforced polypropylene hybrid composite (BGRP) fairly decreased after aging at $25^{\circ} \mathrm{C}$ for 6 months while they reduced significantly after aging at $75^{\circ} \mathrm{C}$ for 3 months. [25] They studied the mechanical properties of sisal fiber, polypropylene composite by the addition of glass fiber. Malic Anhydride was used as a compatibilizer for polypropylene. The mechanical properties of Hemp-Polypropylene composites was also increased by addition of glass fibers. [26] Samples were then tested for their mechanical properties. The total fiber content was fixed to 30\% in order to study its effect on mechanical properties on specimens. By increasing the glass fiber contents, insignificant increase in tensile and flexural properties of the hybrid composites was observed.

M.Ramesh et.al. [27] blended natural fibers with glass fibers. They incorporated sisal and jute with glass fibers using polyester as a matrix. The effect of strain rate on fracture and ductility of the material can be analyzed by using the impact test. The mechanical properties namely tensile, and flexural indeed increased on the addition of glass fibers but the tensile properties showed dramatic increase in case of jute-GFRP whereas impact strength and flexural strength were more for Sisal-GFRP.

R.S.Rana et.al. [28] worked upon blending of natural fiber composites along with the glass fiber. They used sisal fiber incorporated into epoxy composite which were reinforced by glass fiber. It was seen that upto $4 \%$ concentration of sisal and glass fibre, the tensile strength increases. But on further increase of sisal fiber, tensile strength decreases, which is due to decrease in bonding between reinforcement and matrix material due to decrease in concentration of matrix. Same behavior is seen in case of flexural and impact strength as well

Moe MoeThwe et.al. [29] prepared composites consisting of Bamboo fibers and bamboo-glass fiber reinforcing the polypropylene matrix and studied for their degradation due to environmental factors. It was observed that the tensile strength degradation and moisture absorption capacity was improved by the addition of Malic Anhydride as a coupling agent. When both BGRP (Bamboo-glass fiber reinforced polymer) and BFRP (Bamboo fiber reinforced polymer) were exposed to water, due to aging both of them showed reduced tensile and modulus strength. It was also seen that the polymer which were reinforced by glass fibers (BGRP) showed better resistance to environmental aging.

The effect of addition of glass fiber to composite made of polyester and ramie fiber was studied by Daiane Romanzini [30]. Samples prepared by Resin Transfer Molding were characterized for FTIR, TGA analysis. Density measurements were done. Mechanical testing like Impact and flexural were also performed. Overall fiber loading was kept constant at $21 \%$ only the composition of glass and ramie fiber was varied. FTIR was used to locate the position of various functional groups; spectra of which revealing hydroxyl, $\mathrm{C}=\mathrm{O}$ and $\mathrm{C}-\mathrm{H}$ groups. The flexural strength of $45 \%$ composition of ramie fiber was found to be more than other compositions and that of neat polyester. Upon addition of glass fiber, strength further increased. Same trend was observed for impact strength. This happens due to better stress transfer capacity of glass fiber than ramie fiber.

\section{SOME OTHER RESEARCH:}

M.S. Sreekala et.al. fabricated composites using banana fiber and glass fiber. Addition of glass fiber made the phenol formaldehyde composite more brittle. With increase in fiber loading, tensile, flexural as well as impact strength increased. [31]. S.M. Sapuan et.al. researched on the composites made by kenaf/glass epoxy and found it suitable to be used in passenger car bumper beam[32]. K. Sabeel Ahmad found that properties of jute composites can be increased by the addition of glass fiber. [33]R. Velmurugan et. al. found that the addition of glass fibers decreased the moisture capacity of composites. [34] 
CONCLUSION: Table wise summary of the various research is summarized in following table

\begin{tabular}{|c|c|c|}
\hline Author & $\begin{array}{l}\text { Brief summary of work } \\
\text { done }\end{array}$ & Conclusion \\
\hline $\begin{array}{l}\text { Christopher Wonderlya, } \\
\text { Joachim } \\
\text { Grenestedta,Go GranFernlundb, } \\
\text { Elvis Cepus }\end{array}$ & $\begin{array}{l}\text { A comparison between the } \\
\text { mechanical properties of } \\
\text { carbon fiber and glass fibre } \\
\text { reinforced vinyl ester } \\
\text { composite was studied }\end{array}$ & $\begin{array}{l}\text { - Tensile strength results: The glass fiber } \\
\text { specimens typically produced XGM failures } \\
\text { i.e. explosive failure in the gage area. Carbon } \\
\text { fiber composite showed more tensile strength } \\
\text { than glass fiber composite. } \\
\text { - Compression strength results: The glass fiber } \\
\text { showed higher values than the carbon fiber } \\
\text { composite. } \\
\text { Open Hole tensile Strength: The OHT strength } \\
\text { is lower than the tensile strength for carbon } \\
\text { specimen. }\end{array}$ \\
\hline $\begin{array}{l}\text { Jiang Zhu, Ashraf Imam, } \\
\text { Roger Crane, Karen Lozano, } \\
\text { Valery N. Khabashesku , } \\
\text { Enrique V. Barrera }\end{array}$ & $\begin{array}{l}\text { They prepared vinyl etser } \\
\text { composite reinforced with } \\
\text { glass fiber which were } \\
\text { enhanced by carbon } \\
\text { nanotube addition and } \\
\text { interlaminar shear strength } \\
\text { was studied. }\end{array}$ & $\begin{array}{l}\text { - The interlaminar shear strength was } \\
\text { significantly improved by the addition of } \\
\text { nanotubes and other properties like flexural } \\
\text { strength can also be achieved. }\end{array}$ \\
\hline $\begin{array}{l}\text { S. Mishra, A.K. Mohanty, } \\
\text { L.T. Drzal, M. Misra, S. } \\
\text { Parija, S.K. Nayak, S.S. } \\
\text { Tripathy }\end{array}$ & $\begin{array}{l}\text { Sisal and Pineapple fiber } \\
\text { composites were prepared } \\
\text { in the polyester resin } \\
\text { which were further } \\
\text { reinforced by glass fibers. } \\
\text { Their mechanical } \\
\text { properties and water } \\
\text { absorption capacity was } \\
\text { studied. }\end{array}$ & $\begin{array}{l}\text { - The addition of glass fiber resulted in increase } \\
\text { of tensile, impact as well as flexural strength } \\
\text { of the composites. }\end{array}$ \\
\hline $\begin{array}{l}\text { Kasama Jarukumjorn } \\
\text {,NitinatSuppakarn }\end{array}$ & $\begin{array}{l}\text { Synthesized } r \text { sisal- } \\
\text { polyproplene composites } \\
\text { which were further } \\
\text { reinforced by glass fiber } \\
\text { addition. }\end{array}$ & $\begin{array}{l}\text { - Mechanical properties like tensile strength and } \\
\text { flexural strength were significantly increased. }\end{array}$ \\
\hline $\begin{array}{l}\text { Shang-Han Wu, Feng-Yih } \\
\text { Wang, Chen-Chi. M. Ma } \\
\text { Wen-Chi Chang, Chun-Ting } \\
\text { Kuo, Hsu-Chiang Kuan, Wei- } \\
\text { Jen Chen }\end{array}$ & $\begin{array}{l}\text { Studied the mechanical } \\
\text { properties of polyamide- } 6 \\
\text { polyamide-6/clay } \\
\text { nanocomposites which } \\
\text { were reinforced by carbon } \\
\text { fiber and glass fibers }\end{array}$ & $\begin{array}{l}\text { - It was observed that the polyamide-6/clay } \\
\text { nanocomposites were far better than the } \\
\text { polyamide-6 nanocomposites, mechanical } \\
\text { properties (tensile and flexural) of both which } \\
\text { increased on increase of fiber content. Notched } \\
\text { izod impact strength decreased on addition of } \\
\text { fiber. }\end{array}$ \\
\hline $\begin{array}{l}\text { M. Ramesh , K. Palanikumar, } \\
\text { K. Hemachandra Reddy }\end{array}$ & $\begin{array}{l}\text { Prepared composites } \\
\text { which consisted of glass } \\
\text { fiber reinforced sisal, jute } \\
\text { fibers separately as well as } \\
\text { a blend of all } 3 \text { fibers and } \\
\text { studied their mechanical } \\
\text { properties. }\end{array}$ & $\begin{array}{l}\text { - The mechanical properties namely tensile, and } \\
\text { flexural indeed increased on the addition of } \\
\text { glass fibers but the tensile properties showed } \\
\text { dramatic increase in case of jute-GFRP } \\
\text { whereas impact strength and flexural strength } \\
\text { were more for Sisal-GFRP. }\end{array}$ \\
\hline $\begin{array}{l}\text { J. L. Thomason* and M. A. } \\
\text { Vlug }\end{array}$ & $\begin{array}{l}\text { Studied the effect of glass } \\
\text { fiber length on } \\
\text { polypropylene composites } \\
\text { also the stiffness of }\end{array}$ & $\begin{array}{l}\text { - The laminate stiffness was found to increase } \\
\text { also the modulus increased upto the fiber } \\
\text { length of } 0.5 \mathrm{~mm} \text {. }\end{array}$ \\
\hline
\end{tabular}




\begin{tabular}{|c|c|c|}
\hline & composite material & \\
\hline $\begin{array}{l}\text { R. S. Rana,Ashish kumre, } \\
\text { Saraswati Rana, and Rajesh } \\
\text { Purohit }\end{array}$ & $\begin{array}{l}\text { Prepared and studied for } \\
\text { the epoxy composites } \\
\text { reinforced by glass and } \\
\text { sisal fiber. }\end{array}$ & $\begin{array}{l}\text { - The tensile, impact and flexural behavior } \\
\text { followed the same trend i.e. they increased } \\
\text { upto fiber concentration of } 4 \% \text { and further } \\
\text { decreased. }\end{array}$ \\
\hline $\begin{array}{l}\text { D.M. Laura, H.Keskulla, J.W. } \\
\text { Barlow, D.R. Pau }\end{array}$ & $\begin{array}{l}\text { Used nylon-6 as matrix } \\
\text { and reinforced it with glass } \\
\text { fiber. Also glass fiber used } \\
\text { was treated with coupling } \\
\text { agents so as to improve } \\
\text { their performance. }\end{array}$ & $\begin{array}{l}\text { Treatment of fiber with octyl silane gave } \\
\text { maximum value of tensile strength whereas } \\
\text { treatment with anhydride silane showed high } \\
\text { value of impact strength. }\end{array}$ \\
\hline Moe MoeThwe, Kin Liao & $\begin{array}{l}\text { Polypropylene matrix was } \\
\text { used and bamboo fiber and } \\
\text { bamboo-glass fiber were } \\
\text { used as reinforcement. } \\
\text { Environmental effects } \\
\text { were studied on these } \\
\text { composites. }\end{array}$ & $\begin{array}{l}\text { - It was observed that composites reinforced by } \\
\text { glass fiber showed higher resistance to } \\
\text { environmental aging. }\end{array}$ \\
\hline $\begin{array}{l}\text { Seena Joseph, M.S. Sreekala, } \\
\text { Z. Oommen, P. Koshy, sabu } \\
\text { Thomas }\end{array}$ & $\begin{array}{l}\text { Used Glass and banana } \\
\text { fiber as well to prepare } \\
\text { phenol formaldehyde } \\
\text { composite. }\end{array}$ & $\begin{array}{l}\text { - Mechanical properties increased with increase } \\
\text { in fiber loading. }\end{array}$ \\
\hline $\begin{array}{l}\text { M.M. Davoodi, S.M. Sapuan, } \\
\text { D.Ahmad, Aidy Ali, A. } \\
\text { Khalina, Mehdi Jonoobi }\end{array}$ & $\begin{array}{lr}\text { Prepared } & \text { epoxy } \\
\text { composites } & \text { using } \\
\text { kenaf/glass fibers } & \text { as } \\
\text { reinforcement. } & \\
\end{array}$ & - $\quad$ Found it suitable for use in car bumpers. \\
\hline
\end{tabular}

\section{ADVANTAGES AND DISADVANTAGES OF USING GLASS FIBER:}

It was seen that using glass fiber provides many advantages like reduction in moisture absorption capacity as compared to bamboo fibers as seen in work done by Moe Moe et.al (30), S. Mishra et al (21) and Kasama Jarukumjorn et.al. (22). Samples which require more tensile strength, impact strength and flexural strength can use glass fiber as a better reinforcing material as compared to the traditional natural fibers like sisal, jute etc. Composites which are reinforced by glass fibers, show more resistance to environmental aging thus it can be effectively used where long term use is needed. Also they can be used in areas which require moisture tolerance like frequent submerging in water like cooling towers. Since cooling towers are always wet, they have to be protected from rust, corrosion, and other safety issues. Due to the excellent properties of fiberglass, it is used in these towers as screening to keep people and animals away from the danger zones.

\section{REFERENCES:}

1. Fazeli, M.; Florez, J.; Simão, R. (9 November 2018). "Improvement in adhesion of cellulose fibers to the thermoplastic starch matrix by plasma treatment modification". Composites Part B: Engineering. 163: 207216. doi:10.1016/j.compositesb.2018.11.048

2. Karmaker AC, Youngquist JA. Injection molding of polypropylene reinforced with short jute fibers. J Appl Polym Sci 1996;62:1147-51.

3. Chand N, Hashmi SAR. Mechanical properties of sisal fiber at elevated temperature. J Mat Sci 1993;28:6724-8.

4. Devi U, Bhagawan SS, Thomas S. Mechanical properties of pineapple leaf fiber-reinforced polyester composites. J Appl Polym Sci 1997;63:1739-48.

5. White NM, Ansell MP. Straw reinforced polyester composites. J Mat Sci 1983;18:1549-56. 
6. Sanadi AR, Prasad SV, Rohatgi PK et al. fiber reinforced polyester. Part I. Analysis of tensile and impact properties. J Mat

Sci 1986;21:4299-304.

7. Woodhams RT, Thomas G, Rodgers DK. Wood fibers as reinforcing fillers for polyolefins. PolymEng Sci 1984;24:1166-71.

8. Shin FG, Xian XJ, Zheng WP et al. Analysis of the mechanical properties and microstructure of bambooepoxy composites. J Mat Sci 1989;24:3483-90.

9. Erhard, Gunter. Designing with Plastics Trans. Martin Thompson. Munich: Hanser Publishers, 2006.

10. Ilschner, B; et al. (2000). Composite Materials. Ullmann's Encyclopedia of Industrial Che]istry. Weinheim, Germany: Wiley-VCH Verlag GmbH \& Co. KGaA. doi:10.1002/14356007.a07_369. ISBN 9783527306732

11. E. Fitzer; et al. (2000). Fibers, 5. Synthetic Inorganic. Ullmann's Encyclopedia of Industrial Chemistry. Weinheim, Germany: Wiley-VCH Verlag $\mathrm{GmbH}$ \& KGaA. doi:10.1002/14356007.a11_001. ISBN 978-3527306732.

12. Mitchell, Steve (November 1999). The birth of fiberglass boats," The Good Ole Boat.

13. Entry for US 232122 A (14-Sep-1880)". US Patent Publication. Retrieved 9 October 2013.

14. M R Sanjay*, B Yogesha. Studies on Natural/Glass Fiber Reinforced Polymer Hybrid Composites: An Evolution Materials Today: 4 (2017) 2739-2747

15. M Ramesh, K Palanikumar, K Hemachandra Reddy. Composites. Procedia Engineering: 51, 2013, pp.745 750 .

16. Jiang Zhu, Ashraf Imam, Roger Crane et al. Processing a glass fiber reinforced vinyl ester composite with nanotube enhancement of interlaminar shear strength Composites Science and Technology 67 (2007) $1509-1517$

17. ASTM D2344-84. Standard test method for apparent interlaminar shear strength of parallel fiber composites by short-beam method.

18. Shang-Han Wu, Feng-Yih Wang, Chen-Chi et al.sep? Mechanical, thermal and morphological properties of glass fiber and carbon fiber reinforced polyamide- 6 and polyamide- 6 clay nanocomposites Materials Letters 49 2001. 327-333

19. J. L. Thomason* and M. A. Vlug. Influence of fibre length and concentration on the properties of glass fibre-reinforced polypropylene: 1. Tensile and flexural modulus Composites: PartA 27A (1996)477-484

20. D.M. Laura, H.Keskulla, J.W. Barlow et al. Effect of glass fiber surface chemistry on the mechanical properties of glass fiber reinforced, rubber toughened Nylon-6. Polymer 43 (2002) 4673-4687

21. ChristopherWonderlya, Joachim Grenestedta, Goran Fernlundb et al. Comparison of mechanical properties of glass fiber/vinyl ester and carbon fiber/vinyl ester composites Composites: Part B 36 (2005) 417-426

22. ASTM D3039/D3039M-00e1 Standard test method for tensile properties of polymer matrix composite materials. ASTM International, 100 Barr Harbor Drive, P.O. Box C700, West Conshohocken, PA 194282959, USA.

23. S. Mishra, A.K. Mohanty, L.T. Drzal et al. Studies on mechanical performance of biofibre/glass reinforced polyester hybrid composites Composites Science and Technology 63 (2003) 1377-1385

24. Kasama Jarukumjorn *, NitinatSuppakarn. Effect of glass fiber hybridization on properties of sisal fiberpolypropylene Composites Composites: Part B 40 (2009) 623-627

25. Thwe MM, Liao K. Durability of bamboo-glass fiber reinforced polymer matrixhybrid composites. Compos Sci Technol 2003;63:375-87.

26. Sain M, Suhara P, Law $S$ et al. Interface modification and mechanical properties of natural fiber-polyolefin composites products. J Reinf Compos 2005;24(2):121-30

27. M. Ramesh, K. Palanikumar, K. Hemachandra. Reddy Mechanical property evaluation of sisal-jute-glass fiber reinforced polyester composites Composites: Part B 48 (2013) 1-9

28. R.S. Rana, Ashish Kumre, Saraswati rana et al. Characterization of properties of epoxy sisal/glass fiber reinforced hybrid composite materials Today: proceedings 4 (2017) 5445-5451

29. Moe MoeThwe, Kin Liao Durability of bamboo-glass fiber reinforced polymer hybrid matrix composites Composites Science and Technology 63(2003) 375-387

30. DaianeRomanzini, Heitor Luiz OrnaghiJunior, Sandro Campos Amico, Ademir José Zattera. Preparation and characterization of ramie-glass fiber reinforced polymer matrix hybrid composites. Materials Research, 15(3) 2012.

31. Seena Joseph, M.S. Sreekala, Z. Oommen et al. A comparison of the mechanical properties of phenol formaldehyde composites reinforced with banana fibers and glass fibers. Composites Science and 
Technology62(2002)1857-1868

M.M. Davoodi, S.M. Sapuan, D.Ahmad et al. Mechanical properties of hybrid kenaf/glass reinforced epoxy composite for passenger car bumper beam. Materials and Design 31 (2010) 47927-4932

32. K.Sabeel Ahmed, S Vijayarangan. Tensile, flexural and interlaminar shear properties of woven jute and jute-glass fabric reinforced polyester composites. Journal of Materials Processing Technology 207 (2008) 330-335

33. R. Velmurugan, V. Manikandan. Mechanical properties of palmyra/ glass fiber hybrid composites Composites Part A 38 (2007) 2216-2226 